\title{
The Twilight of the Colombian Paramilitary
}

\author{
Ryan E. Holroyd, Pennsy/vania State University
}

\begin{abstract}
The following article discusses the development of Colombia's paramilitary army, the Autodefensas Unidas de Colombia (AUC), beginning in the 1990s and ending with the destruction of the organisation in the late 2000s. The AUC was originally founded by three brothers surnamed Castaño as a private army designed to combat the Fuerzas Armadas Revolucionarias de Colombia (FARC) and other Columbian revolutionary guerrilla groups. The main argument put forward in the article is that when the AUC was initially founded, the primary goal of its leaders, the Castaño brothers, was a sincere desire to check and, if possible, destroy the power of the FARC. In the process of its development however, the AUC came to depend on the taxation of cocaine to fund its war against the guerrillas. When the Colombian state, which had been too weak to prevent the development of either the AUC or the FARC in the 1990s, strengthened its military power in the 2000s, it demanded the AUC cease its operations, demobilise its military forces, and aid the state in destroying the cocaine industry's infrastructure in southern Colombia. The Castaño brother who had become the organisation's sole leader, Carlos, was willing to comply, but his move to end the AUC's association with the cocaine industry invoked the wrath of his subordinate commanders, resulting in his brutal murder. This event revealed that the AUC had gradually developed into a cocaine cartel in the guise of a paramilitary army despite the intentions of its leader, who was killed because his leadership became a threat to the profitable taxation of cocaine that his former subordinate commanders enjoyed.
\end{abstract}

\section{Introduction}

After the fall of the Medellín cocaine trafficking cartel in the early 1990s, Colombia saw a new player emerge in the complex struggle between the state and private armies in the country's southern hinterland. The Autodefensas Campesinas de Córdoba y Urabá (ACCU) was a paramilitary group, a private army equipped with modern weapons and capable of dominating large swaths of territory in southern Colombia where the state's military could not maintain control. From 1994 to 1997, the ACCU developed into the largest and most powerful paramilitary army in the history of the 
country, and in 1997 it absorbed most of the other smaller paramilitary armies into an ACCU-lead federation, christened the Autodefensas Unidas de Colombia (AUC). ${ }^{1}$ The principle architects of the AUC were the Castaño brothers, Fidel, Carlos, and José Vicente, who, by their own accounts were motivated by the loss of their father to assassins of the Marxist guerrilla army, the Fuerzas Armadas Revolucionarias de Colombia (FARC). The army that they created was unlike Colombia's socialist or Marxist revolutionary guerrillas, the drug cartels, or even the paramilitary "self defence" armies that had preceded it. Though every bit as violent as these other organisations, the AUC maintained a nominal allegiance to the Colombian state and insisted that its primary goal was the destruction of Colombia's revolutionary guerrilla armies until the death of its leader, Carlos Castaño, in 2004. To the Colombian state, the AUC was officially just as illegal as the guerrilla armies, but they were occasionally a valuable ally in the struggle against guerrillas, and as a consequence, certain officers and units in the Colombian military tolerated and sometimes even cooperated with the AUC.

This, however, began to change in the early 2000s, and especially after the election of President Álvaro Uribe Vélez in 2002. Uribe's administration was faced with the legacy of the dismal failure of its predecessor's attempt to negotiate a peace settlement with the FARC, and pressure was mounting from the American government, which wanted to see serious results from the recent significant increase in the aid it was giving to the Colombian government to fight terrorism and drug trafficking. The Uribe administration promised to take a tougher stance against both the guerrillas and paramilitaries. Peace from a position of power was the new goal, and to accomplish this, the Colombian military was strengthened and increasing military pressure was put on the guerrilla armies. As the formal military power of the state grew thanks to American logistic and financial aid, and the internal reorganisation of the military, the usefulness of the counterrevolutionary paramilitaries as a check

\footnotetext{
${ }^{1}$ For simplicity's sake, except when referring specifically to the pre-1997 group, I will refer to both organisations together as the "AUC".

Past Imperfect
}

17 [2011] | @ | ISSN 1711-053X | elSSN 1718-4487 
against the guerrillas diminished, and their previous links to the Colombian military became an embarrassment. In response to the Uribe administration's declaration that they would no longer tolerate the paramilitaries, but were willing to negotiate a demobilisation process with them, the AUC declared a unilateral ceasefire in 2002. The negotiations that followed developed a plan for the demobilisation and disarmament of the AUC, and, by 2006, 30,151 AUC soldiers had supposedly been demobilised and 16,983 weapons of various types had been surrendered to the Colombian state. $^{2}$

Yet, there are still powerful private armies at large in Colombia. Something went wrong with the demobilisation of the AUC, and whatever it was radically altered the complexion of the Colombian state's struggle for a monopoly on the use of violence. This article traces the evolution of paramilitarism, from the destruction of the Medellín Cartel in 1993 to 2009, and explores the factors that led to the creation of a unified, ideologically motivated, counterrevolutionary force powerful enough to challenge the guerrillas, but, at the same time, so fragile that after the death of its leader it almost immediately broke into innumerable splinter groups.

Most of the credit for designing and nurturing the AUC belongs to Carlos Castaño and, to a lesser degree, his brother Fidel, though Fidel did not live long enough to see much of its development. But the creation of the organisation would not have been possible without the unique conditions of the 1990s. Central state authority was relatively weak and the military could not effectively cope with the growing power of the guerrillas. The fall of the Medellín and Cali cartels gave both the FARC and the AUC an opportunity to grow immensely wealthy and powerful by taking control of the cocaine industry in the regions where they were dominant. But, as Carlos would discover, there was a fine-line between paramilitaries financed with drug money, and mere drug lords with private armies.

2 Lisa J. Laplante and Kimberly Theidon, "Transitional Justice in Times of Conflict: Colombia's Ley de Justica y Paz," Michigan Journal of International Law 28, no. 1 (Fall 2006), 66. 
The reassertion of the state's formal military power in the 2000s diminished the usefulness of the AUC; Carlos Castaño proposed divorcing the organisation from the drug trade and discovered too late that the AUC had crossed that line.

\section{Los Pepes \& the Origins of the AUC, 1989 - 1994}

In 1989, Colombian President Virgilio Barco Vargas' administration abolished Law 48 of 1968, which had legalised the formation of the private armies that are now commonly known as "paramilitaries". These armies were theoretically intended to protect rural farmland and to assist the regular military against revolutionary insurgent groups like the FARC and the smaller Ejército de Liberación Nacional (ELN) that had arisen in the wake of Colombia's period of Violencia. ${ }^{3}$ The rationale behind the abolition of this law was clear; by 1989, the state lost any semblance of control it had over the many and varied private "counterrevolutionary" and "self-defence" armies spread across Colombia and they were becoming a threat to the stability of the nation. The previous year, 1988, was a particularly bloody one for Colombia. According to Amnesty International, the paramilitaries were responsible for more than eighty massacres, ${ }^{4}$ which, the Colombian government itself concluded, meant that the paramilitaries managed to surpass even the revolutionaries in the taking of lives. ${ }^{5}$ Had the paramilitaries limited themselves to killing FARC and ELN soldiers, it would probably not have been a concern for Barco and his government. Yet, various paramilitary groups decided to broaden their list of targets. Rural civilians, including children, from communities thought by the paramilitaries to be collaborating with the revolutionaries were now

\footnotetext{
3 Fernando Cubides C., "From Private to Public Violence: The Paramilitaries," in Violence in Colombia, 1990-2000: Waging War and Negotiating Peace, edited by Charles Bergquist, Ricardo Peñaranda, and Gonzalo Sánchez G. (Wilmington: Scholarly Resources, 2001), 131 and Laplante, 54.

${ }^{4}$ Amnesty International, Political Violence in Colombia: Myth and Reality (London: Amnesty International Publications, 1994), 56.

${ }^{5}$ Harvey F. Kline, State Building and Conflict Resolution in Colombia, 1986 - 1994 (Tuscaloosa: The University of Alabama Press, 1999), 75. 
legitimate targets, as were members of the teachers' federation, politicians from the legal leftist Unión Patriótica (UP) party, and, in 1989 , even a governmental investigation committee. ${ }^{6}$

To make matters worse, more and more of the paramilitaries were getting involved with the largest cocaine trafficking organisation that arose in the 1980s, the Medellín Cartel,7 and it was becoming more difficult to tell the counterrevolutionary paramilitary armies and the private armies of drug lords apart. By the mid-1989 there were about 11,000 soldiers in private armies, not counting the revolutionary guerrillas, and many of these were sponsored by the Medellín Cartel. ${ }^{8}$ As Harvey F. Kline, a professor of political science at the University of Alabama, observed, the marriage between paramilitary groups and the Medellín Cartel was a highly logical, maybe even an inevitable outcome, because the successful drug trafficking lords often invested their profits in rural farmland, which was exactly what the paramilitaries had been created to protect. ${ }^{9}$

This relationship initially proved comfortable and profitable for the paramilitaries who had become involved with the Medellín Cartel. Yet, when the de facto boss of the Medellín Cartel, Pablo Emilio Escobar Gaviria, declared war on the Colombian state in 1989 and began a terrorist campaign against Colombian society at large, these paramilitaries were put in an awkward position. ${ }^{10}$ In addition to losing their legal status with the abolition of Law 48, some paramilitary units known to be working directly for Medellín bosses were attacked by the Colombian military, ${ }^{11}$ and others were convinced to surrender their weapons to the state. ${ }^{12}$ The loss of the war and subsequent destruction of the Medellín Cartel were serious blows to the paramilitaries, reducing their power throughout Colombia.

\footnotetext{
6 Ibid., 65-66.

7 Patrick L. Clawson and Rensselaer W. Lee III, The Andean Cocaine Industry (New York: St. Martin's Press, 1996), 53.

8 Ibid.,53.

${ }^{9}$ Kline, 72.

10 Mark Bowden, Killing Pablo: The Hunt for the World's Greatest Outlaw (New York: Atlantic Monthly Press, 2001), 59.

11 Kline, 77.

12 Ibid., 144.
} 
But the end of Escobar's war did not signal an end to Columbian paramilitarism. Some leaders predicted the impending demise of the Medellín Cartel, and switched sides in the war, attacking their former employers in the cartel. The most important group of these apostates called themselves Los Pepes (which was a creative acronym for "Perseguidos por Pablo Escobar", or the "People persecuted by Pablo Escobar"), and was founded and led by Fidel Castaño, who was a self-described one-time friend of Escobar. ${ }^{13}$ In early 1993, Los Pepes began a terrorist campaign against Escobar's property, businesses, and associates; setting fire to his family's residences, detonating bombs in or near businesses owned by him, and assassinating his employees, associates, and family members. In short, Los Pepes was able to hurt Escobar in ways that the Colombian police, bound as they were by the laws of the land, could not. More than one source credits Los Pepes with playing a key role in bringing about the grisly demise of Escobar on December $2,1993.14$

During the Medellín Cartel war, branches of the Colombian military and law enforcement agencies were accused by human rights activists, the American government's Drug Enforcement Administration (DEA), and most vehemently by Escobar himself of cooperating and sharing information with Los Pepes.15 It is now clear that they were all correct. Carlos Castaño later stated while

\footnotetext{
13 In an interview with Semana, Fidel Castaño claims that he was principal organiser and leader of Los Pepes. "'Yo Fui el Creador de Los Pepes"," Semana.com, June 27, 1994, http://www.semana.com/wf_InfoArticulo.aspx?IdArt=54972 (accessed March 14, 2009). Mark Bowden in his book, Killing Pablo, cites a secret memo written by the American government's Drug Enforcement Administration's chief of financial investigations, Gregory Passic, who lists Mireya Galeano, Raphael Galeano, Freddy Paredes, and Eugenio Ramirez along with Fidel and his brother, Carlos, as the leaders of Los Pepes. Bowden, 197. 14 See Bowden, p. 263 and Ron Chepesiuk, The Bullet or the Bribe: Taking Down Colombia's Cali Drug Cartel (Westport: Praeger Publishers, 2003), p. 146-147 for examples. There is even a rumour that it was Carlos Castaño himself, rather the Colombian government special forces, who shot Escobar, "'The police didn't kill Pablo Escobar, Carlos Castaño did"," Colombia Reports, November 7, 2008, http://www.colombiareports.com/colombian-news/news/1953-the-police-didntkill-pablo-escobar-carlos-castano-did.html (accessed March 15, 2009). 15 Amnesty International, Political Violence in Colombia, 59, Bowden, 197, and Human Rights Watch/Americas, State of War: Political Violence and Counterinsurgency in Colombia (New York: Human Rights Watch, 1993), 55-56. Past Imperfect 17 [2011] | () | ISSN 1711-053X | eISSN 1718-4487
} 
writing about his experiences with Los Pepes, "We were tolerated by the Attorney General, the police, the army, the DAS [Departamento Administrativo de Seguridad] and even President Cesár Gaviria Trujillo, who never ordered that we be pursued."16 Colonel Hugo Martínez of the Bloque de Búsqueda, the special police unit assigned to hunt Escobar, also admits that his men worked with Fidel Castaño's men. ${ }^{17}$

Officially, though, Los Pepes remained a criminal organisation. After the brutal murder of Guido Parra, an attorney who had worked for Escobar, in April 1993, President César Gaviria Trujillo's administration, which succeeded Barco's in 1990, offered a USD\$1.39 million reward for the capture of the leaders of Los Pepes, but, unsurprisingly, the reward was left unclaimed.18 After Escobar's death, Los Pepes was dissolved, and Fidel Castaño returned to his base in the Department of Córdoba to focus on leading his paramilitary group, the ACCU. ${ }^{19}$ The pattern of official denouncement and unofficial toleration and sometimes cooperation set by the state's relationship with Los Pepes would persist as the triadic guerrilla-paramilitary-state conflict developed through the 1990s.

The Rise of the Paramilitaries, 1994 - 2002

16 I have taken the translation of this quote from William Avilés, "Paramilitarism and Colombia's Low-Intensity Democracy," Journal of Latin American Studies 38, no. 2 (May 2006), 395.

17 Bowden, 263. Diego Murillo Bejarano, sometime known as "Don Berna", was apparently a frequent messenger for Los Pepes to the Bloque de Búsqueda.

Following the end of the cartel war, Murillo became a high ranking member of AUC, and was one the thirteen ex-AUC commanders extradited to the United States on May 13, 2008. Juan Forero, "Colombia Sends 13 Paramilitary Leaders to U.S," The Washington Post, May 14, 2008, http://www.washingtonpost.com/wpdyn/content/article/2008/05/13/AR2008051300800.html (accessed March 15, 2009).

18 Bowden, 195 and Chepesiuk, 146, 263.

19 Kline, p. 149. The ACCU existed before the Medellín Cartel war, but was apparently a small operation; in 1986 it numbered only ninety-three men according to the Colombian Ministry of National Defense. Nazih Richani, Systems of Violence: The Political Economy of War and Peace in Colombia (Albany: State University of New York Press, 2002), 123. 
For the government of Colombia, the most unfortunate aspect of the fall of the cocaine cartels was the strengthening of the FARC. Once the two great cartels (first the Medellín then later the Cali Cartel, the other large cocaine trafficking association in Colombia) were destroyed, control of the cocaine industry fell to smaller enterprises, most of which lacked the resources to continue smuggling the vast quantities of cocaine from Peru and Bolivia into Colombia for re-export as the cartels had. ${ }^{20}$ This, along with an intensified effort by the Peruvian president, Alberto Fujimori, and his administration to stem the flow of cocaine from Peru to Colombia, forced the bulk of South America's coca production to shift from Peru to southern Colombia in the 1990s, where the state remained too weak to prevent the cultivation of coca. Colombian coca production is estimated to have risen from twenty percent to seventy-five percent of the Andes region's total between 1993 and 1999. 21 Colombia's coca industry's greatest development was in the southern departments of Putumayo, Caquetá, and Guaviare, ${ }^{22}$ all traditional FARC strongholds, which gave the FARC access to vastly increased revenues. ${ }^{23}$ In 1997, the FARC made an estimated USD $\$ 381$ million from cocaine, ${ }^{24}$ and their ranks expanded to 18,000 men, which made them the largest guerrilla army in Latin American history. ${ }^{25}$

The FARC, newly energised and expanded by cocaine money, was a challenge that the Colombian military was not prepared to face. The military was not poorly funded, but its effectiveness was seriously compromised by inefficient organisation. Through the 1990s, more than seventy percent of defence spending went to salaries, pensions, maintenance, logistics, medical services, and housing, with twenty percent or less left for upgrading armaments. ${ }^{26}$

\footnotetext{
20 Peceny, 101.

21 Ibid., 107-108.

22 Richani, 95.

${ }^{23}$ Ricardo Vargas Meza, "The FARC, the War and the Crisis of the State," NACLA

Reports on the Americas 31, no. 5 (March/April 1998), p. 22 and Peceny, 108.

24 Francisco E. Thoumi, Illegal Drugs, Economy, and Society in the Andes (Washington:

Woodrow Wilson Center Press, 2003), 105.

25 Richani, 74.

26 Ibid., 45.
} 
Although Colombia's military personnel totalled 179,000 people, by the late 1990s, only 23,000 professional soldiers were engaged fighting the guerrillas, which gave the military only a slight numeric edge on the guerrillas. ${ }^{27}$ The military therefore chose a defensive strategy, seeking to protect vital areas of the country and contain the FARC and the other guerrilla groups in their established territories rather than attempting to attack them directly.

The Colombian military desperately needed assistance in its fight against the FARC, and it was the Castaño brothers who offered it. Fidel, and later Carlos, claimed that their decision to get involved in paramilitarism was motivated by the kidnapping and murder of their father by the FARC in 1981. This often repeated story certainly lends credence to Fidel's claim that the Castaños were motivated by a sincere desire to see the destruction of the guerrillas, rather than by a pursuit of wealth and power. ${ }^{28}$ Carlos Castaño, who became the ACCU's commander after Fidel's death in 1994, supported his latebrother's claim with his characteristic bluntness. When asked by Time's Tim McGirk if he thought the AUC could be a replacement for the state, he stated:

[If you ask a Colombian], he won't hesitate in saying that he wants to live without an AUC presence, and without a guerrilla presence. He wants to live where there's a strong, solid state, where there are jobs and stability. The AUC is accepted, but it's not what Colombians want. The solution isn't the AUC. We're part of the solution. ${ }^{29}$

We can accept or reject the Castaños' claim that the paramilitaries were an "antidote" for the poison of the guerrillas, as

\footnotetext{
27 Ibid., 47.

28 Ibid.

29 Tim McGirk, "Drugs, Violence and Peace: A Colombian Gunman Speaks," Time, November 22, 2000,

http://www.time.com/time/world/article/0,8599,89366,00.html (accessed March 18, 2009). 
Carlos put it in another part of his conversation with Tim McGirk, ${ }^{30}$ and were not seeking wealth or power for themselves. But, whatever their motivation, from the perspective of the Colombian government, their usefulness as a balance against the ascendant FARC of the 1990s is obvious. In the important Magdalena Medio region of the Departments of Antioquia and Santander, the FARC had been the predominant force beginning in the early 1980s, but had been driven out by the mid 1990s, not by the army, but by paramilitary groups. ${ }^{31}$ By the late 1990s, the AUC, by then equipped with military helicopters and other aircraft, ${ }^{32}$ was able to challenge the FARC in its home territory in the southern departments, ${ }^{33}$ something the Colombian military remained reluctant to do because it was devoting the majority of its resources to service its administrative structure rather than increasing its combat capacity. But perhaps the most significant contribution that the AUC made in the war against the guerrillas was the fear it was able to inspire by massacring rural civilians suspected of collaborating with guerrillas, ${ }^{34}$ thereby making it much more difficult for the guerrillas to find civilians willing to collaborate. This campaign of terror that the AUC waged against the real, suspected, and potential supporters of the guerrillas was something that the Colombian military simply could not have done on the same scale, as it was an agent of a democratically-elected civilian government that could not afford to be seen using the nation's military to slaughter large numbers of its own people.

William Avilés, a professor of political science at the University of Nebraska, calls this process of shifting the brunt of the war against the guerrillas to the paramilitaries "privatisation of repression." He suggests that Colombia's political elite were complicit in the campaign of terror against the guerrillas' real and

30 Tim McGirk, "King of the Jungle," Time, November 27, 2000.

http://www.time.com/time/magazine/article/0,9171,998583-1,00.html (accessed March 18, 2009).

31 Clawson, 186-190. These groups were not part of the ACCU, and not yet officially affiliated with the AUC, which formed in 1997.

32 Richani, 124.

33 Ricardo Vargas Meza, "A Military-Paramilitary Alliance Besieges Colombia,"

NACLA Report on the Americas 32, no. 3 (November/December 1998), 37.

34 Ibid., 37. 
potential supporters, if not in the individual acts of terrorism. His claim is that the paramilitaries murdered legal, left-leaning politicians and labour activists who posed the greatest challenge to what he sees as the "neo-liberal" agenda of the government, and that the Colombian political elite tacitly supported these murders through inaction. The Colombian government, especially during the administrations of Ernesto Samper Pizano (1994 to 1998) and Andrés Pastrana Arango (1998 to 2002) was therefore unwilling, rather than merely unable, to do anything to inhibit the growth of the paramilitaries' power. ${ }^{35}$ Avilés' claim rests on the apparent convenience of the murders of left-leaning politicians and activists for the ruling elite, with little direct evidence of connivance at the highest levels of power in the Colombian government and military. However, the evidence that individual commanders in the military cooperated with the paramilitaries is much stronger. In two different publications in the early 2000s, Human Rights Watch details how certain units in the Colombian military routinely exchanged information and shared equipment with AUC, and often allowed them to act freely, even when this meant standing by as the paramilitaries massacred civilians. ${ }^{36}$ Carlos Castaño himself claimed that there were no formal links, but the AUC did cooperate with low ranking officers in the police and military. ${ }^{37}$

In fairness to the Colombian government and military during Pastrana's administration, it should be noted that in the last two years of that administration, the arrest rate of paramilitaries rose dramatically, and, on at least one occasion, the Colombian military actually attacked AUC troops, shooting down one of their helicopters. ${ }^{38}$ The Pastrana administration also began restructuring

35 William Avilés, "Paramilitarism and Colombia's Low-Intensity Democracy," Journal of Latin American Studies 38, no. 2 (May 2006), 379-408.

${ }^{36}$ Human Rights Watch, The Ties that Bind: Colombia and Military-Paramilitary Links (New York: Human Rights Watch, 2000), and Human Rights Watch, The "Sixth Division": Military-Paramilitary Ties and U.S. Policy in Colombia (New York: Human Rights Watch, 2001).

37 Tim McGirk, "King of the Jungle."

38 Juan 0. Tamayo, "Colombia Shows Off 2 Rightist Guerrillas," The Miami Herald, May 3, 2001 and Reuters, "Colombia Shoots Down Copter That Aided Paramilitary Fighters," The New York Times, May 7, 2002, 
the military in 1999. The number of professional soldiers was increased to 60,835 , soldiers' pay was raised, and the size of the support staff was decreased.39 Pastrana's successor, Álvaro Uribe Vélez, continued to restructure and strengthen the military in an effort to make it an effective combat force.

Uribe's Policies \& Carlos' Acquiescence, 2002 - 2004

Uribe was elected in 2002 with the apparent approval of Carlos Castaño. According to Castaño, Uribe was "the man closest to our philosophy." 40 Like the Castaño brothers, Uribe lost his father to FARC assassins in the $1980 \mathrm{~s},{ }^{41}$ and similarly he seemed determined to permanently destroy the power of the guerrillas in Colombia. During his campaign, he promised to further expand the Colombian military, and after he was elected he made good on this promise. The number of professional soldiers in the Colombian military by 2008 was about $80,000.42$ The military changed its tactics and began targeting the FARC's leadership with surprise strikes, while encouraging common guerrilla soldiers to desert. As a result, the military successfully whittled the FARC down from approximately 16,000 to 20,000 soldiers in 2001 to about 9,000 in 2008.43 Instead of passively defending economically important areas, or attempting to negotiate a peace settlement with the FARC by offering concessions as had the Pastrana administration, the Uribe administration strengthened the military and took the fight to the jungles with the goal of destroying the FARC, or at least weakening

http://www.nytimes.com/2002/05/07/international/americas/07COLO.html (accessed March 19, 2009).

39 Richani, 58.

40 This translated quote is from Grace Livingstone, Inside Colombia: Drugs, Democracy and War (London: Latin America Bureau, 2003), 220.

41 Jeremy McDermott, "Profile: Alvaro Uribe Velez," BBC News World Edition, August 7, 2002, http://news.bbc.co.uk/2/hi/americas/1996976.stm (accessed March 20, 2009).

42 "After Sureshot," The Economist, May 29, 2008,

http://www.economist.com/world/americas/displaystory.cfm?story_id=11455759 (accessed March 20, 2009).

43 The 2001 estimate is from Livingstone, 203, and the 2008 estimate is from "After Sureshot." 
them to the point that they would agree to a peace settlement favourable to the state.

Part of the credit for this policy change must be given to the American government, which, especially during the administration of George W. Bush, pressured the Colombian government to take a more active role in fighting both Colombia's drug industry and all of its independent armies. The Uribe administration benefited from Washington's heightened concern; from 2002 to 2006, the Colombian government received an average USD $\$ 572$ million per year in military/police aid, compared to an average USD \$304 million from 1997 to 2001.44 As well, between 1999 and 2004, 37,001 Colombian trainees received American military training; the number of trainees increased almost every year from 2476 in 1999 to its peak at 12,947 trainees in 2003 (in 2004 the number dropped to 8801, which was still substantially more than any other nation except Afghanistan). ${ }^{45}$

Where did this leave the AUC? On September 10, 2001, it ignominiously joined the ELN and the FARC on the American government's list of terrorist organisations, the day before the attacks on the World Trade Centre and the Pentagon, ${ }^{46}$ and the Colombian military was continuing the attacks on the AUC that it begun during the Pastrana administration. ${ }^{47}$ Because the Colombian state was now leading the war against the FARC, which was partially funded by an American government opposed to Colombia's paramilitary, the AUC became an inconvenient embarrassment for the state, especially as pro-human rights groups began to publish

\footnotetext{
${ }^{44}$ Lisa Haugaard, Adam Isacson, and Joy Olson. Erasing the Lines: Trends in U.S. Military Programs with Latin America (Washington: Latin America Working Group Education Fund, Center for International Policy, and Washington Office on Latin America, 2005), 18, http://www.ciponline.org/facts/0512eras.pdf (accessed March $20,2009)$.

45 Ibid., 5-7. The statistics provided do not include the training of Iraq's new army by American personnel.

46 Peceny, 112.

47 The Associated Press, "Colombian Government Troops Kill 20 Rebel Fighters," The New York Times, August 10, 2002.

http://www.latinamericanstudies.org/auc/metro-block.htm (accessed March 20, 2009). 
material linking the military to the paramilitaries. ${ }^{48}$ The Uribe administration wanted to end paramilitarism in Colombia, and Castaño was apparently willing to oblige. In response to Uribe's promises to take a harder line against all of Colombia's illegal armies, Castaño told Luis Jaime Acosta in an article for The Guardian in September 2002 that he respected the legitimacy of the state and that the AUC would dissolve if the state was prepared to fight the guerrillas alone. ${ }^{49}$ Evidently true to his word, in 2002 Castaño and the AUC began holding secret talks with the Colombian government, and, in December, Castaño declared a unilateral ceasefire so that the AUC could begin open negotiations with the government. ${ }^{50}$ On July 15,2003 , the first of two agreements between the state and the AUC was signed at Santa Fe de Ralito in the Department of Córdoba. ${ }^{51}$ Under the agreement, the AUC was to concentrate its troops in specified areas in order to be demobilised by government inspectors, and in the meantime support the government's anti-drug producing and trafficking initiatives. ${ }^{52}$

It seemed as though Carlos Castaño succeeded in guiding his counterrevolutionary army towards a decisive peace-settlement with the state that would finally put an end to paramilitarism in Colombia, leaving the military to finish the fight with the revolutionary guerrillas alone. Yet, something went terribly wrong within the AUC itself - something that was not immediately obvious to outside observers until it was too late. On April 16, 2004, less than a month before the second agreement would be signed at Santa Fe de Ralito, Carlos Castaño was assassinated by Jesús Ignacio

${ }^{48}$ See Human Rights Watch, The Ties that Bind: Colombia and Military-Paramilitary Links (New York: Human Rights Watch, 2000) and Human Rights Watch, The "Sixth Division": Military-Paramilitary Ties and U.S. Policy in Colombia (New York: Human Rights Watch, 2001).

49 Luis Jaime Acosta, "Peace Overtures from Colombia's King of the Paramilitaries," The Guardian, September 9, 2002,

http://www.guardian.co.uk/world/2002/sep/09/colombia (accessed March 22, 2009).

50 "Colombia Right-Wing Truce Takes Force," BBC News World Edition, December 1, 2002. http://news.bbc.co.uk/2/hi/americas/2528147.stm (accessed March 21, 2009).

51 Amnesty International, Colombia: The Paramilitaries in Medellín: Demobilization or Legalization? (Amnesty International, August 31, 2005), 11-12.

52 Ibid., 12. 
Roldán (known as "Monoleche" to his associates) the bodyguard of the third Castaño brother who had helped Fidel and Carlos build the ACCU, José Vicente Castaño. ${ }^{53}$ According to both Ignacio Roldán and another former AUC commander, Ever Veloza García (who used the alias "Hernan Hernandez", and in some sources is called "Hebert Veloza García"), it was Vicente, in collusion with many of the highest ranking bosses in the AUC, who had ordered his brother's murder. ${ }^{54}$ Vicente denied involvement in his brother's murder, but all sources agree that Carlos was killed by fellow paramilitaries. ${ }^{55}$

\section{The Abandonment of the AUC \& a Return to a Simpler Time, $2004-2009$}

It is clear Carlos was not killed because of the negotiated demobilisation and his plans to dismantle the AUC. After his murder, his second in command, Salvatore Mancuso Gómez assumed official control of the AUC, or what was left of it, and signed the second Santa Fe de Ralito agreement on May 13, 2004.56 The first blocks of paramilitaries began demobilising in late 2003,57 and, as of 2008, over 30,000 men and women went through the process. ${ }^{58}$ Most of the important commanders of the former-AUC also surrendered to

53 Jan McGirk, “Carlos Castaño," The Independent, Obituaries, September 6, 2006, http://www.independent.co.uk/news/obituaries/carlos-castantildeo-414777.html (accessed March 21, 2009), and "Revealed: The Secrets of Colombia's Murderous Castaño brothers," Telegraph.co.uk, November 8, 2008,

http://www.telegraph.co.uk/news/worldnews/southamerica/colombia/3391789/ Revealed-The-secrets-of-Colombias-murderous-Castano-brothers.html (accessed March 21, 2009), which identifies a restaurant as Carlos' place of death. 54 Chris Kraul, "Sibling Linked to Colombia Militia Leader's Death," Los Angeles Times, September 4, 2006, http://articles.latimes.com/2006/sep/04/world/fg-colombia4 (accessed March 21, 2009) and "Destape de un jefe 'para'," Semana.com, August 4, 2007, http://www.semana.com/noticias-nacion/destape-jefe-para/105404.aspx (accessed March 21, 2009). Ignacio Roldán's testimony was made more credible when he was able to lead investigators to the shallow grave he claimed to have put Carlos in.

55 "Las autodefensas queremos negociar con los gringos," Semana.com, October 7, 2006, http://www.semana.com/noticias-nacion/autodefensas-queremos-negociargringos/97422.aspx (accessed April 6, 2009).

56 Amnesty International, Colombia: The Paramilitaries in Medellín, 12.

57 Human Rights Watch, Smoke and Mirrors: Colombia's Demobilization of Paramilitary Groups (New York: Human Rights Watch, 2005), 25.

58 Felipe Gómez Isa, Paramilitary Demobilisation in Colombia: Between Peace and Justice (Madrid: Fundación para las Relaciones Internacionales y el Diálogo Exterior, Working Paper no. 57, 2008). 
the state, including Mancuso, Carlos Mario Jiménez Naranjo (known as "Macaco") Rodrigo Tovar Pupo (known as "Jorge 40"), Diego Fernando Murillo Bejarano (known as "Don Berna" or "Adolfo Paz"), Hernán Giraldo, and Freddy Rendón Herrera (known as "El Alemán").59 The majority of the most powerful paramilitary bosses were apparently not opposed to dissolving the AUC itself.

So why was Carlos Castaño assassinated if he and the other AUC bosses evidently agreed on the AUC's demobilisation? Where Castaño truly differed from his subordinates was in his attitude towards the cocaine industry. Like the FARC, the fledgling ACCU benefited from the vacuum left in the cocaine trafficking market after the destruction of the Medellín and Cali cartels. The ACCU had taken control of many cocaine producing regions and, even more importantly, the Urabá region near the Panamanian border, which allowed them to control a major cocaine smuggling artery out of Colombia. ${ }^{60}$ Castaño admitted on more than one occasion that the AUC taxed coca growers to fund its operations, and estimates suggest that as much as eighty percent of AUC's funds came from cocaine. ${ }^{61}$ Publicly, Castaño claimed to have mixed feelings about the AUC's dependency on drugs, and claimed to support the Colombian government's efforts to eradicate the drug trade. When Tim McGirk asked about the apparent contradiction in supporting the government's plan to destroy cocaine plantations, while continuing to tax them, Castaño replied:

We're not opposed to eradicating the coca fields, but as long as those crops are there, and guerrillas are nearby, we'll keep asking for a tax from the coca growers. This doesn't mean we're narcos. We don't

59 "Colombia Extradites Militia Head," BBC News, May 7, 2008, http://news.bbc.co.uk/2/hi/americas/7388354.stm (accessed March 23, 2009), Juan Forero, "Colombia Sends 13 Paramilitary Leaders to U.S," and "Uribe's offer 'took me by surprise': Karina," Colombia Reports, March 12, 2009,

http://www.colombiareports.com/colombian-news/news/3203-uribes-offer-tookme-by-surprise-karina.html (accessed March 22, 2009). By far the most important boss who did not surrender was Vicente Castaño.

60 Richani, 123-124.

61 Ibid., 109. 
export drugs, we tax the coca paste. It's just a phase, but the war on drugs does affect us. It will reach us. ${ }^{62}$

By 2002, he was talking openly of the dangers of involvement in the cocaine trade and even suggested the time had come to wean the AUC off drug money. With almost disturbing prescience he told Martha Elvira Soto F. and Orlando Restrepo of El Tiempo that:

We accept the money collected from the coca producers, but it is very difficult to set a limit of how far the drug traffic can finance a war. It tends to turn the fighters into mercenaries. This is what happened with the police and it has even happened in the FARC. Once people have been corrupted by the drug trade, nobody can control them. We are looking for the least contemptible way to fund the organization. ${ }^{63}$

It would have been easy to dismiss these statements as nothing more than public relations manoeuvres on Castaño's part until 2008 when the ex-AUC boss Ever Veloza, who had been captured by police in April 2007 decided to hand over a USB memory stick to the authorities that contained copies of e-mails sent by Carlos to Vicente and other AUC leaders before his murder.64 From these e-mails it is clear that Carlos was becoming increasingly concerned about the dependence on the cocaine trade, and that his relationship with the other commanders was deteriorating over the issue. In these e-mails he pleads with fellow AUC commanders, asking them to help abolish the cocaine trade, and attempts to appeal to their sense of righteousness. In one poignant example, in an e-mail he sent to all the AUC commanders on March 19, 2003, in

62 Tim McGirk, "Drugs, Violence and Peace."

${ }^{63}$ Martha Elvira Soto F. and Orlando Restrepo, "Anarchy in Colombia," El Tiempo, June 30, 2002, http://www.worldpress.org/Americas/648.cfm (accessed March 22, 2009).

64 “Alias 'HH' Entrega Testamento de Carlos Castaño," Semana.com, July 9, 2008, http://www.semana.com/noticias-on-line/alias-hh-entrega-testamento-carloscastano/113435.aspx (accessed March 22, 2009).

Past Imperfect

17 [2011] | 디 |ISSN 1711-053X | eISSN 1718-4487 
which he restates his case for abandoning cocaine, the gulf between Carlos and his subordinates is clear.

Letter to the commanders of the AUC,

It is clear what Adolfo [Murillo] said yesterday: "If it wasn't for the drug trafficking we wouldn't be sitting here". That is sensible: without drug trafficking we wouldn't have so many men in the AUC today; we would have less, but we would be truly politically legitimate and strong, and today we wouldn't be sitting here resorting to our last chance, but we would be fulfilling our duty, because neither the USA nor national and international opinion would be demanding the actual Colombian government eradicate the [AUC]. ${ }^{65}$

The information on Veloza's memory stick provides unique glimpses into the world of the AUC at its twilight, and gives us some insight for judging Carlos Castaño's character as well. Without it, we would have to continue to guess at the reasons behind Castaño's murder in 2004. Castaño did publicly claim that he disliked the drug trade and planned to reduce the AUC's dependence on it. But, by the time of his death, there was very little evidence that he or anyone else in the organisation had started to dismantle the AUC-controlled cocaine industry. This was a serious reason to question the sincerity of Castaño's claims. Pablo Escobar once claimed that ultimately he too was an enemy of the FARC. But doubting Castaño's claims still leaves the question of the motivation behind his murder. The

65 “Con Esos Amigos...," Semana.com, August 9, 2008,

http://www.semana.com/noticias-nacion/esos-amigos/114344.aspx (accessed March 22, 2009). This was originally published on Semana.com.

"Carta a los comandantes de las AUC":

"Es claro lo que dijo Adolfo ('Don Berna') ayer: "si no fuera por el narcotráfico no estaríamos aquí sentados". Eso es sensato: sin el narcotráfico no seríamos hoy tantos hombres en las AUC; seríamos menos, pero realmente legítimos y fuertes políticamente, y hoy estaríamos no sentados aquí recurriendo a la última salida, sino que estaríamos cumpliendo con nuestro deber, porque ni los EU ni la opinión nacional e internacional le estarían exigiendo al actual gobierno colombiano que erradique las Autodefensas."

I would like thank Carolina Muñoz Miranda for kindly providing me with this translation. 
simplest answer pivots on an internal power struggle where someone, possibly his own brother (if Veloza and Ignacio Roldán are believed), wanted to replace him as the head of one of Colombia's richest criminal organisations. The difficulty with that hypothesis is that Castaño was preparing to demobilise the AUC and his subordinates were also willing to go through with it after his death. Why then did they want him dead? Fortunately the e-mails in Veloza's memory stick have preserved Castaño's pleas to his subordinate commanders to take what he apparently believed was the right course of action for the organisation.

What he believed was the right course of action caused a conflict over the cocaine trade that alienated Carlos Castaño from the organisation he and Fidel built. As the AUC grew through the 1990s, it appeared to be a strongly united, ideologically motivated, true counterrevolutionary paramilitary force. As long as paramilitarism and profiting from the cocaine trade were compatible goals, it succeeded in this role. But when Carlos sought to re-establish the legitimacy of the AUC and himself as a paramilitary leader by helping to dismantle not only the AUC, but also the infrastructure of the cocaine industry to which it was attached, his subordinates revealed their true interests by leaving Carlos in a shallow, unmarked grave with his honour intact, but his body riddled with bullets. For all purposes, the AUC and the form of paramilitarism it represented died with Carlos, and it appears that his former subordinates were only too happy to see it go as they quickly proceeded with the demobilisation process he had negotiated.

As pro-human rights groups have taken pains to show, the demobilisations presented opportunities for former paramilitaries. For the average soldier, Decree 128, passed on January 22, 2003, gave an automatic pardon for the possession of illegal weapons and membership in an illegal group upon its demobilisation if they were not under investigation as an individual for a serious crime (murder, kidnapping, terrorism, etc.), even if the group they had belonged to was known to have committed these crimes. The ex-paramilitary soldier was also not required to divulge any information on his or 
her previous group. ${ }^{66}$ Because of the lack of a system for verifying the identities of the former paramilitaries and tracking them after the demobilisations, concerns were raised that the demobilisations did nothing to inhibit further paramilitary activity. Amnesty International, in an investigation of demobilised paramilitaries in Medellín, claims that many of them were "recycled", meaning they went through the demobilisation process and then soon after rejoined the armed group from which they demobilised.67 Garry Leech, a journalist and editor of Colombia Journal, claims that in some cases the real paramilitaries did not even have to bother going through the demobilisation process themselves. Instead they paid unemployed rural civilians to pretend to be paramilitary soldiers and demobilise for them. ${ }^{68}$

For the former AUC commanders, most of who were under investigation for specific crimes beyond participation in an armed group, Decree 128 did not apply. To encourage them to surrender, the government passed the "Justice and Peace" law on July 22, 2005.69 This law set the penalty for non-pardonable offences committed by paramilitaries at between five to eight years of incarceration, but left the nature of the incarceration ambiguous. ${ }^{70}$ According to Amnesty International, an even more important aspect of the law was that it was supposed to have protected the excommanders from extradition to the United States by defining paramilitarism as a "political crime"; those found guilty of "political crimes" were not extraditable. ${ }^{71}$ Unfortunately for the excommanders, this proved not to be the case. In May 2006, the "Justice and Peace" law was altered to make the relatively short prison sentences for ex-paramilitaries contingent on cooperation with police investigations and reparations to the families of their

${ }^{66}$ Amnesty International, Colombia: The Paramilitaries in Medellín, 19-20.

67 Ibid., 38-39.

68 Garry Leech, Beyond Bogotá: Diary of a War Journalist in Colombia (Boston: Beacon Press, 2009), 196.

${ }^{69}$ Amnesty International, Colombia: The Paramilitaries in Medellín, 22.

70 Ibid., 22. Amnesty International suggests that some of these sentences may be served in "agricultural colonies" in the ex-AUC commanders' home territories.

71 Ibid., 24. 
victims. Predictably, a spokeswoman for the incarcerated exparamilitaries accused the government of going back on its word, saying, "This is very serious, because they are not complying with accords that were made during negotiations." 72 In spite of this protest, on May 7, 2008 the ex-AUC commander Jiménez was put on a DEA plane bound for the United States, ${ }^{73}$ and less than a week later thirteen other commanders, including Mancuso, Tovar, Murillo, and Giraldo followed, because, according to Uribe, "the government cannot tolerate their return to crime, their failure to truly and efficiently collaborate with justice." 74

Like Amnesty International, the ex-AUC commanders laboured under the false impression that the Colombian state would remain true to their original agreements. If it had, the former paramilitaries would have served their five to eight year sentences in relative comfort, while maintaining contact with, and probably control of the cocaine trafficking organisations that they had developed during the AUC's ascendancy in the 1990s and early 2000s. At the conclusion of their sentence, they would have been able to re-emerge absolved of the crimes they committed as paramilitaries, and either enjoy the wealth they had accumulated in that guise, or devote themselves again to the cocaine trade where their true interests had always lain.

\section{Epilogue \& Conclusion}

The removal of the old ex-AUC bosses did not put an end to private armies in Colombia. Instead it simply fragmented them further, returning paramilitarism to the state of disunity in which it had been before the rise of the Medellín and Cali cartels. It is estimated by the Colombian think-tank Corporación Nuevo Arco Iris that, as of late 2008, one hundred new clusters of armed

\footnotetext{
72 Juan Forero, "Court Overrules Parts of Law Shielding Colombia's Warlords," The New York Times, May 20, 2006,

http://www.nytimes.com/2006/05/20/world/americas/20colombia.html?pagewa nted=print (accessed March 23, 2006).

73 "Colombia Extradites Militia Head," BBC News, May 7, 2008, http://news.bbc.co.uk/2/hi/americas/7388354.stm (accessed March 23, 2009).

74 Juan Forero, "Colombia Sends 13 Paramilitary Leaders to U.S."

Past Imperfect
}

17 [2011] | @ | ISSN 1711-053X | elSSN 1718-4487 
paramilitaries had emerged in Colombia. ${ }^{75}$ Some, like the Águilas Negras appeared to be trying to follow in the footsteps of Castaño's AUC by threatening trade unionists, politicians, and activists. ${ }^{76}$ Many though, like the groups controlled by the cocaine trafficking lords Daniel Barrera (who, like many of his AUC predecessors, maintained a colourful alias: "El Loco")77 and Daniel Rendón (known as "Don

Mario"), the brother of the extradited ex-AUC commander Freddy Rendón, seemed much more interested in following in the footsteps of Pablo Escobar and the Medellín Cartel. Rendón, for example, offered a COP\$2 million reward for every policeman murdered in the Department of Antioquia. ${ }^{78}$

The rise of the AUC was a unique phenomenon that redefined paramilitarism in Colombia, if only briefly. It was not simply a front for a cocaine cartel's private army, as most paramilitaries had been in the late 1980s, or a revolutionary army that sought to usurp the state's authority like the FARC and other guerrilla groups. The AUC did resemble its nemesis, the FARC, in several important respects, though. Like the FARC, it was one of the greatest beneficiaries from the destruction of the two cocaine cartels. And also like the FARC, profiting from cocaine was a means to end rather than its primary motivation, at least until the death of its foremost architect, Carlos Castaño.

The AUC existed during the 1990s and early 2000s because of several exceptional factors that aligned perfectly after the destruction of the cartels. The first was the emergence of its charismatic, committed, and ruthless leader, Castaño. The desperate

\footnotetext{
75 "Preocupante Aumento de Bandas Armadas en Colombia," Semana.com, November 26, 2008, http://www.semana.com/noticias-conflictoarmado/preocupante-aumento-bandas-armadas-colombia/118126.aspx (accessed March 23, 2009).

76 Ibid.

77 Rory Carroll and Sibylla Brodzinsky, "Colombian Drug Lord's Ranch Becomes Dinosaur Park - But Trade is Far from Extinct," The Guardian, November 26, 2008, http://www.guardian.co.uk/world/2008/nov/26/drugs-trade-cocaine-columbiaescobar (accessed March 23, 2009).

78 Luis Jaime Acosta and Helen Popper, "Colombian Drug Lord Puts Price on Police Heads," Reuters, January 23, 2009,

http://www.reuters.com/article/americasCrisis/idUSN23321872 (accessed March $23,2009)$. 
pleas he made to his fellow commanders to help the government dismantle Colombia's insidious cocaine infrastructure, and return to a path of "legitimacy" are compelling evidence of Castaño's sincerity when he claimed that he supported the state and wished only to see the destruction of the guerrillas. Castaño's sins were wrath, and perhaps pride, but not avarice. It took his leadership and vision to weld the disparate groups of fighters into a united, vicious, and goaloriented paramilitary army that could meet the challenge of the guerrillas.

But meeting the challenge of the guerrillas also required the money from the post-cartel, AUC-controlled, cocaine production. The AUC was, in part, a response to the FARC's increased strength that stemmed from its increased share of cocaine production, and the inability of the state to effectively deal with it. The guerrillaparamilitary conflict existed before the 1990s, but without money from cocaine, neither the guerrillas nor the AUC's paramilitary predecessors were able to afford either the advanced military equipment or the sheer numbers of soldiers that they could in the 1990s. The relative weakness of the Colombian military prevented it from checking the rise of the FARC's power alone, no less dealing with both the guerrillas and the AUC at once. As a result, until the early 2000s, the military took a defensive posture, which allowed the AUC to grow in strength with little interference from the state, while also providing it with an enemy that was a nearly-perfect match because both were the products of almost exactly the same circumstances.

The circumstances changed in the early 2000s, and especially after Uribe's administration took power. The American government increased military aid to Colombia, but also made it clear that it was no longer acceptable to passively tolerate the paramilitaries, who were by that point as deeply involved in the cocaine industry as the guerrillas. The newly-invigorated Colombian military began an effective campaign against the FARC itself, and began to apply pressure on the AUC to disband. 
The primary reason for the AUC's existence, keeping the FARC in check, came to an end with the reassertion of the state's military power. This did not, however, mean an end to paramilitarism in Colombia. But 2009 should not be seen as a return to 1989; because of its own internal reorganisation and American patronage, the Colombian military remains relatively strong. Though, many of the AUC's old networks have remained in place, none of the various fragmented groups have yet managed to reconstitute themselves into either a pan-Colombian paramilitary army or drug cartel, and as of yet, no leader has emerged who could become either a second Carlos Castaño or Pablo Escobar. 